\title{
Front Matter: Volume 8264
}

, "Front Matter: Volume 8264," Proc. SPIE 8264, Integrated Optics: Devices, Materials, and Technologies XVI, 826401 (13 March 2012); doi:

10.1117/12.930626

SPIE. Event: SPIE OPTO, 2012, San Francisco, California, United States 


\section{PROCEEDINGS OF SPIE}

\section{Integrated Optics: Devices, Materials, and Technologies XVI}

Jean Emmanuel Broquin

Gualtiero Nunzi Conti

Editors

23-25 January 2012

San Francisco, California, United States

Sponsored and Published by

SPIE

Volume 8264

Proceedings of SPIE, 0277-786X, v. 8264 
The papers included in this volume were part of the technical conference cited on the cover and title page. Papers were selected and subject to review by the editors and conference program committee. Some conference presentations may not be available for publication. The papers published in these proceedings reflect the work and thoughts of the authors and are published herein as submitted. The publisher is not responsible for the validity of the information or for any outcomes resulting from reliance thereon.

Please use the following format to cite material from this book:

Author(s), "Title of Paper," in Integrated Optics: Devices, Materials, and Technologies XVI, edited by Jean Emmanuel Broquin, Gualtiero Nunzi Conti, Proceedings of SPIE Vol. 8264 (SPIE, Bellingham, WA, 2012) Article CID Number.

ISSN 0277-786X

ISBN 9780819489074

Published by

SPIE

P.O. Box 10, Bellingham, Washington 98227-0010 USA

Telephone +1 3606763290 (Pacific Time) · Fax +1 3606471445

SPIE.org

Copyright (C) 2012, Society of Photo-Optical Instrumentation Engineers

Copying of material in this book for internal or personal use, or for the internal or personal use of specific clients, beyond the fair use provisions granted by the U.S. Copyright Law is authorized by SPIE subject to payment of copying fees. The Transactional Reporting Service base fee for this volume is $\$ 18.00$ per article (or portion thereof), which should be paid directly to the Copyright Clearance Center (CCC), 222 Rosewood Drive, Danvers, MA 01923. Payment may also be made electronically through CCC Online at copyright.com. Other copying for republication, resale, advertising or promotion, or any form of systematic or multiple reproduction of any material in this book is prohibited except with permission in writing from the publisher. The CCC fee code is 0277-786X/12/\$18.00.

Printed in the United States of America.

Publication of record for individual papers is online in the SPIE Digital Library.

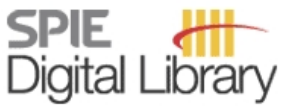

SPIEDigitalLibrary.org

Paper Numbering: Proceedings of SPIE follow an e-First publication model, with papers published first online and then in print and on CD-ROM. Papers are published as they are submitted and meet publication criteria. A unique, consistent, permanent citation identifier (CID) number is assigned to each article at the time of the first publication. Utilization of CIDs allows articles to be fully citable as soon as they are published online, and connects the same identifier to all online, print, and electronic versions of the publication. SPIE uses a six-digit CID article numbering system in which:

- The first four digits correspond to the SPIE volume number.

- The last two digits indicate publication order within the volume using a Base 36 numbering system employing both numerals and letters. These two-number sets start with $00,01,02,03,04$, $05,06,07,08,09,0 A, 0 B \ldots 0 Z$, followed by 10-1Z, 20-2Z, etc.

The CID number appears on each page of the manuscript. The complete citation is used on the first page, and an abbreviated version on subsequent pages. Numbers in the index correspond to the last two digits of the six-digit CID number. 


\section{Contents}

ix Conference Committee

xi Introduction

xiii $\quad$ Spinoptics: Spin degeneracy removal in nanostructures (Plenary Paper) [8269-100]

V. Kleiner, N. Shitrit, E. Hasman, Technion-Israel Institute of Technology (Israel)

\section{SESSION 1 WAVEGUIDE ENGINEERING I}

826403 Magneto-optical mode conversion in a hybrid glass waveguide made by sol-gel and ion-exchange techniques [8264-02]

F. Royer, H. Amata, Univ. de Lyon (France) and Univ. Jean Monnet Saint-Etienne (France); F. Parsy, IMEP-LAHC (France); D. Jamon, Univ. de Lyon (France) and Univ. Jean Monnet Saint-Etienne (France); E. Ghibaudo, J.-E. Broquin, IMEP-LAHC (France); S. Neveu, PECSA, CNRS, Univ. Pierre et Marie Curie (France)

826406 Fabrication of barrier-type slab waveguides in $\mathrm{Er}^{3+}$-doped tellurite glass by single and double energy $\mathrm{MeV} \mathrm{N}^{+}$ion implantation [8264-05]

I. Bányász, Wigner Research Ctr. for Physics (Hungary); Z. Zolnai, Research Ctr. for Natural Sciences (Hungary); S. Pelli, Istituto di Fisica Applicata Nello Carrara (Italy); S. Berneschi, Enrico Fermi Ctr. for Study and Research (Italy) and Istituto di Fisica Applicata Nello Carrara (Italy); G. Nunzi-Conti, Istituto di Fisica Applicata Nello Carrara (Italy); M. Fried, T. Lohner, P. Petrik, Research Ctr. for Natural Sciences (Hungary); M. Brenci, G. C. Righini, Istituto di Fisica Applicata Nello Carrara (Italy)

\section{SESSION 2 AMPLIFIERS AND LASERS}

$826409 \quad 1.55 \mu \mathrm{m}$ hybrid waveguide laser made by ion-exchange and wafer bonding [8264-08] M. Casale, D. Bucci, L. Bastard, J.-E. Broquin, IMEP-LAHC (France)

8264 OB Analytical modeling of mid-infrared silicon Raman lasers [8264-10] J. Ma, S. Fathpour, CREOL, The College of Optics and Photonics, Univ. of Central Florida (United States)

\section{SESSION 3 PHOTONIC INTEGRATION}

8264 OC Hybrid silicon/III-V laser sources based on adiabatic mode transformers (Invited Paper) [8264-11]

B. Ben Bakir, A. Descos, N. Olivier, D. Bordel, P. Grosse, J.-M. Fédéli, CEA-LETI (France) 
8264 OF Highly efficient coupling between a monolithically integrated photonic crystal cavity and a bus waveguide [8264-14]

K. Debnath, K. Welna, M. Ferrera, Univ. of St. Andrews (United Kingdom); K. Deasy, D. Lidzey, The Univ. of Sheffield (United Kingdom); T. F. Krauss, L. O'Faolain, Univ. of St. Andrews (United Kingdom)

8264 OG Polymer waveguides based on silicon optical benches [8264-15]

C. T. Chen, P. K. Shen, C. C. Chang, J. Y. Li, H. L. Hsiao, National Central Univ. (Taiwan);

Y. C. Lee, Centera Photonics Inc. (Taiwan); M. L. Wu, National Central Univ. (Taiwan)

\section{SESSION 4 MODELING}

$8264 \mathrm{OH}$ A perturbation approach for the design of coupled resonator optical waveguides (CROWs) [8264-16]

O. S. Ahmed, M. A. Swillam, M. H. Bakr, X. Li, McMaster Univ. (Canada)

8264 Ol Theoretical model for the effective nonlinearity of surface plasmons based on a Green function formalism [8264-17]

I. De Leon, Univ. of Ottawa (Canada); J. E. Sipe, Univ. of Toronto (Canada); R. W. Boyd, Univ. of Ottawa (Canada) and Institute of Optics, Univ. of Rochester (United States)

8264 0J Modeling and analysis of multiple ring resonator performance as optical filter [8264-18] S. Mandal, Indian School of Mines (India); S. Dey, College of Engineering and Management, Kolaghat (India)

8264 OK Design of multilayered SiON strip waveguide for polarizer applications [8264-19]

V. Priye, J. Prasad, Anamika, Indian School Of Mines (India)

$8264 \mathrm{OL}$ Asymmetrically coupled bus with tunable ring resonators for multiple functionalities: Fano resonance, asymmetrical transmission, and wavelength shifting [8264-20]

W. Ding, C. Qiu, National Univ. of Singapore (Singapore)

\section{SESSION 5 SENSORS I}

$82640 \mathrm{M}$ Enhancing gradient optical force in silicon photonic devices (Invited Paper) [8264-21] H. Li, J. Noh, Y. Chen, M. Li, Univ. of Minnesota, Twin Cities (United States)

$8264 \mathrm{ON}$ Array of subwavelength rectangular structures in palladium for optical hydrogen detection [8264-24]

E. Maeda, T. Matsuki, I. Yamada, J.-J. Delaunay, The Univ. of Tokyo (Japan)

826400 The development of a novel monolithic spectrometer chip concept [8264-22]

S. J. Sweeney, Y. Zhang, I. D. Goodyer, ZiNIR Ltd. (United Kingdom)

$8264 \mathrm{OP}$ On-chip interrogation of a silicon-on-insulator microring resonator-based ethanol vapor sensor with an arrayed waveguide grating (AWG) spectrometer [8264-23]

N. A. Yebo, W. Bogaerts, Z. Hens, R. Baets, Univ. Gent (Belgium) 
$8264 \mathrm{OQ} \quad$ Amorphous photonic membranes for broadband chemical sensing applications (Invited Paper) [8264-25]

S. P. Abbey, R. D. Whaley, Jr., Ohio Univ. (United States)

8264 OR Foil-based optical technology platform for optochemical sensors [8264-26]

S. Kalathimekkad, J. Missinne, Univ. Gent (Belgium); J. D. Arias Espinoza, Holst Ctr. (Netherlands); B. Van Hoe, E. Bosman, Univ. Gent (Belgium); E. Smits, R. Mandamparambil, Holst Ctr. (Netherlands); G. Van Steenberge, J. Vanfleteren, Univ. Gent (Belgium)

8264 OS Compact static Fourier transform spectrometer in glass integrated optics in the NIR and visible domain [8264-27]

A. Creux, A. Morand, P. Benech, IMEP-LAHC (France); B. Martin, Institut de Planétologie et d'Astrophysique de Grenoble (France); G. Grosa, IMEP-LAHC (France); E. Le Coarer, P. Kern, Institut de Planétologie et d'Astrophysique de Grenoble (France)

8264 OT Development of a slow-light spectrometer on a chip [8264-28]

S. Murugkar, I. De Leon, Univ. of Ottawa (Canada); Z. Shi, Institute of Optics, Univ. of Rochester (United States); G. Lopez-Galmiche, J. Salvail, E. Ma, Univ. of Ottawa (Canada);

B. Gao, A. C. Liapis, J. E. Vornehm, Institute of Optics, Univ. of Rochester (United States);

R. W. Boyd, Univ. of Ottawa (Canada) and Institute of Optics, Univ. of Rochester (United States)

\section{SESSION 7 WAVEGUIDE ENGINEERING II}

8264 OW Broad-area laser diode with stable single-mode output and wavelength stabilization [8264-31]

T. Nappez, Thales Avionics S.A. (France); E. Ghibaudo, IMEP-LAHC (France); P. Rondeau, J.-P. Schlotterbeck, Thales Avionics S.A. (France); J.-E. Broquin, IMEP-LAHC (France)

8264 OX Photonic nanojet-induced modes: fundamentals and applications [8264-32]

A. Darafsheh, The Univ. of North Carolina at Charlotte (United States); A. Lupu, Institut d'Electronique Fondamentale, CNRS, Univ. Paris-Sud 11 (France); S. A. Burand, T. C. Hutchens, N. M. Fried, V. N. Astratov, The Univ. of North Carolina at Charlotte (United States)

$82640 Z$ Polymer optical waveguides with reduced in-plane bend loss for electro-optical PCBs [8264-58]

R. Pitwon, Xyratex Technology Ltd. (United Kingdom); C. Smith, Univ. of Southampton (United Kingdom); K. Wang, Univ. College London (United Kingdom); J. Graham-Jones, Plymouth Univ. (United Kingdom); D. R. Selviah, Univ. College London (United Kingdom); M. Halter, Vario-optics AG (Switzerland); A. Worrall, Xyratex Technology Ltd. (United Kingdom)

\section{SESSION $8 \quad$ PLASMONICS}

826412 Integration of nanostructures and waveguide core for surface enhanced Raman spectroscopy: a novel excitation method [8264-38]

S. J. Pearce, M. D. B. Charlton, M. E. Pollard, S. Oo, R. Chen, Univ. of Southampton (United Kingdom) 
826413 Compact optical microcavity structures for enhancement of absorption and transmission cross sections of subwavelength plasmonic devices [8264-39]

C. Min, Y. Huang, L. Yang, G. Veronis, Lovisiana State Univ. (United States)

\section{SESSION 9 OPTOFLUIDICS}

826414 Optofluidic SERS on inkjet-fabricated paper-based substrates (Invited Paper) [8264-41]

I. M. White, Univ. of Maryland, College Park (United States)

826415 Optofluidics: waveguides and devices (Invited Paper) [8264-42]

G. Testa, Istituto per il Rilevamento Elettromagnetico dell'Ambiente, CNR (Italy); Y. Huang, Seconda Università di Napoli (Italy); L. Zeni, Technische Univ. Delft (Netherlands);

P. M. Sarro, Seconda Università di Napoli (Italy); R. Bernini, Istituto per il Rilevamento

Elettromagnetico dell'Ambiente, CNR (Italy)

826416 Vertically coupled polymer microresonators for optofluidic label-free biosensors [8264-43]

C. Delezoide, Lab. de Photonique Quantique et Moléculaire, CNRS, Ecole Normale Supérieure de Cachan (France); J. Lautru, Institut d'Alembert, Ecole Normale Supérieure de Cachan (France); J. Zyss, Lab. de Photonique Quantique et Moléculaire, CNRS, Ecole Normale Supérieure de Cachan (France) and Institut d'Alembert, Ecole Normale Supérieure de Cachan (France); I. Ledoux-Rak, C. T. Nguyen, Lab. de Photonique Quantique et Moléculaire, CNRS, Ecole Normale Supérieure de Cachan (France)

826417 High Q silica microbubble resonators [8264-44]

D. Farnesi, Istituto di Fisica Applicata Nello Carrara (Italy) and Univ. degli Studi di Firenze (Italy); A. Barucci, Istituto di Fisica Applicata Nello Carrara (Italy); S. Berneschi, Museo Storica della Fisica e Ctr. Studi e Ricerche Enrico Fermi (Italy) and Istituto di Fisica Applicata Nello Carrara (Italy); M. Brenci, F. Cosi, G. Nunzi Conti, S. Pelli, G. C. Righini, S. Soria, Istituto di Fisica Applicata Nello Carrara (Italy)

\section{POSTER SESSION}

826418 Polymer waveguide grating couplers for low-cost nanoimprinted integrated optics [8264-34]

M. E. Pollard, S. J. Pearce, R. Chen, S. Oo, M. D. B. Charlton, Univ. of Southampton (United Kingdom)

826419 Sensor for optical characteristics of liquid using gapped waveguides: theory [8264-45] K. Baba, K. Nemoto, Sendai National College of Technology (Japan)

8264 1A Design of multiple nanoring-based metallic nanophotonic superlens [8264-46]

J. Choi, Y. Oh, D. Kim, Yonsei Univ. (Korea, Republic of)

8264 1B Integrated surface plasmon resonance array sensor using semiconductor optical amplifier [8264-47]

G.-Y. Oh, Chung-Ang Univ. (Korea, Republic of); D.-G. Kim, Korea Photonics Technology Institute (Korea, Republic of); H.-S. Kim, T.-K. Lee, B.-H. Lee, Y.-W. Choi, Chung-Ang Univ. (Korea, Republic of) 
8264 IC Experimental measurement of photonic/plasmonic crystal dispersion, applied to the investigation of surface plasmon dispersion for SERS sensing applications [8264-48] M. F. A. Muttalib, S. Z. Oo, M. D. B. Charlton, Univ. of Southampton (United Kingdom)

$8264 \mathrm{lE}$ Analysis of total reflection mirror based on horizontal slot waveguide [8264-50] T.-K. Lee, H.-S. Kim, G.-Y. Oh, B.-H. Lee, Chung-Ang Univ. (Korea, Republic of); D.-G. Kim, Korea Photonics Technology Institute (Korea, Republic of); Y.-W. Choi, Chung-Ang Univ. (Korea, Republic of)

$8264 \mathrm{IF}$ Visible and near infrared wavelength photonic crystal fiber splitter for multiwavelength spectral domain optical coherence tomography [8264-51]

J. B. Eom, Korea Photonics Technology Institute (Korea, Republic of); E. J. Min, B. H. Lee, Gwangju Institute of Science and Technology (Korea, Republic of)

826411 Evaluation of damping ratio in a glass-based guided-wave optical microphone with a diaphragm [8264-54]

M. Ohkawa, K. Murata, T. Sato, Niigata Univ. (Japan)

$8264 \mathrm{lL}$ Colorimetric resonant detection of biochemical agents in mesoporous silicon-based photonic crystals [8264-57]

I. A. Kolmychek, S. E. Svyakhovskiy, T. V. Murzina, Lomonosov Moscow State Univ. (Russian Federation); F. Baldini, G. Ghini, A. Giannetti, C. Trono, G. Nunzi Conti, S. Soria, Istituto di Fisica Applicata Nello Carrara (Italy)

8264 IM Nanosensor technology based on semiconductor nanocrystals [8264-59]

J. Martin, Fraunhofer-Institut für Elektronische Nanosysteme (Germany); U. Staudinger, E. Demir, Leibniz-Institut für Polymerforschung Dresdene e.V. (Germany); C. Spudat, Fraunhofer-Institut für Elektronische Nanosysteme (Germany); P. Pöłschke, B. Voit, Leibniz-Institut für Polymerforschung Dresdene e.V. (Germany); T. Otto, T. Gessner, Fraunhofer-Institut für Elektronische Nanosysteme (Germany)

Author Index 
Downloaded From: https://www.spiedigitallibrary.org/conference-proceedings-of-spie on 26 Apr 2023

Terms of Use: https://www.spiedigitallibrary.org/terms-of-use 


\title{
Conference Committee
}

\author{
Symposium Chair
}

Klaus P. Streubel, OSRAM GmbH (Germany)

Symposium Cochairs

David L. Andrews, University of East Anglia Norwich (United Kingdom) Liang-Chy Chien, Kent State University (United States)

Program Track Chair

Yakov Sidorin, Quarles Brady LLP (United States)

Conference Chairs

Jean Emmanuel Broquin, IMEP-LAHC (France)

Gualtiero Nunzi Conti, Istituto di Fisica Applicata Nello Carrara (Italy)

\section{Conference Cochairs}

Pierre Berini, University of Ottawa (Canada)

Christoph M. Greiner, LightSmyth Technologies, Inc. (United States)

\section{Program Committee}

Pavel Cheben, National Research Council Canada (Canada)

Xudong Fan, University of Michigan (United States)

Helmut Heidrich, Fraunhofer-Institut für Nachrichtentechnik Heinrich-Hertz-Institut (Germany)

Andrea Melloni, Politecnico di Milano (Italy)

Robert L. Nelson, Air Force Research Laboratory (United States)

Jens H. Schmid, National Research Council Canada (Canada)

Frank Schmidt, Konrad-Zuse-Zentrum für Informationstechnik Berlin

(Germany)

Yakov Sidorin, Quarles Brady LLP (United States)

Stefano Taccheo, Swansea University (United Kingdom)

Christoph A. Wächter, Fraunhofer-Institut für Angewandte Optik und Feinmechanik (Germany)

Qiwen Zhan, University of Dayton (United States) 


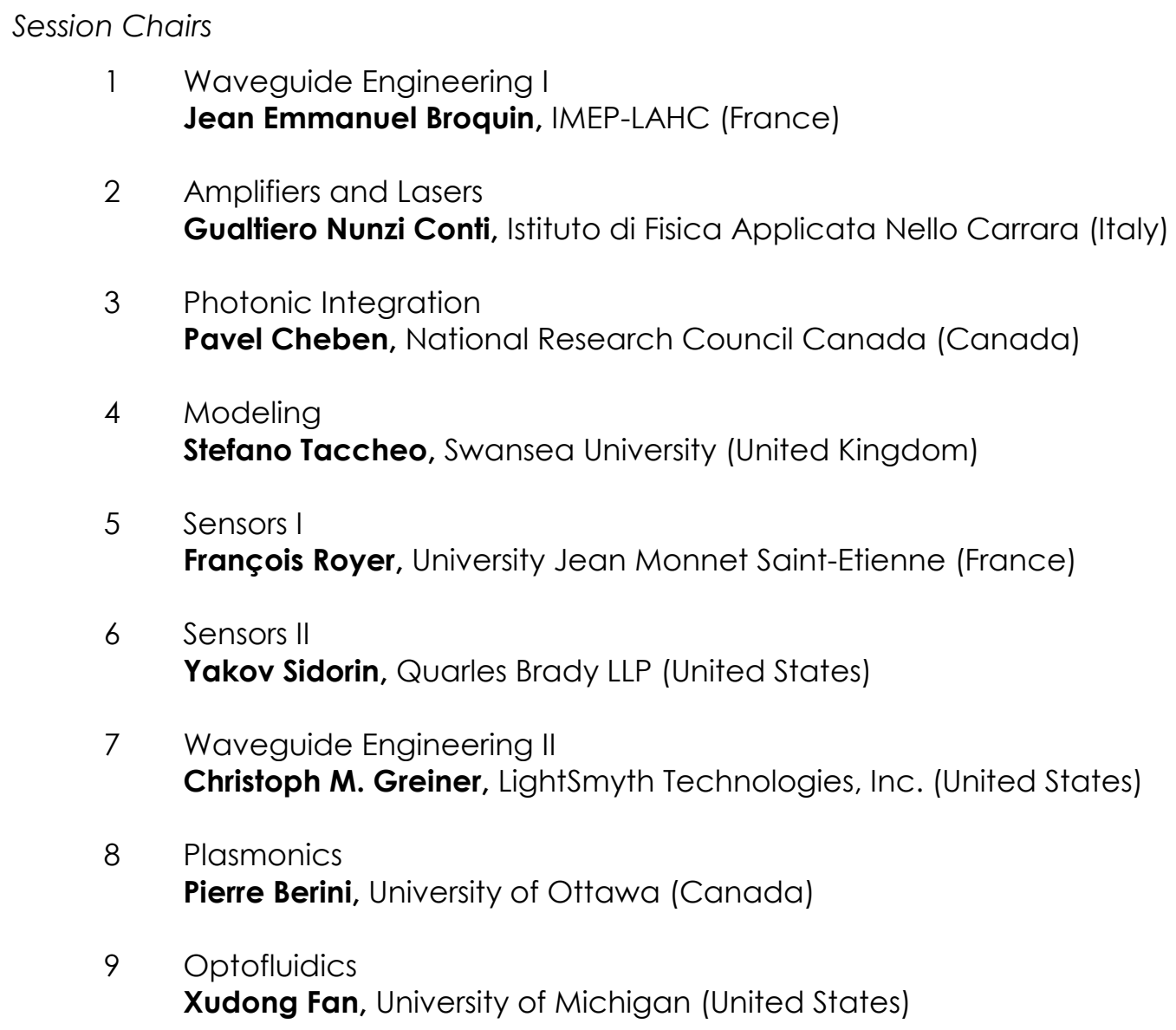




\section{Introduction}

Whether you are a confirmed scientist or a student, whether you are an academic or working for a company, you will find in these proceedings of the sixteenth Photonics West conference on Integrated Optics a picture of that still evolving, dynamic and exciting field.

This year's conference reflected that aspect by its diversity in terms of applications: telecom of course but also a huge diversity of sensors as well as nonlinear optics. Moreover, this variety of uses has also been completed by a great variety of technological and design approaches. From the well-known "silica-on-silicon" based waveguides to new plasmonic devices, from erbiumdoped glass waveguides to polymer ones, our conference covered a technological spectrum as wide as possible since we believe that the crossfertilization of ideas is one of the keys to major breakthroughs in science.

In these proceedings, the reader will therefore see a wide range of exciting advances ranging from new optofluidic devices to different approaches for obtaining magneto-optic waveguides, as well as state of the art photonic integration on silicon chips.

He will also find articles written by students, who quite often gave their first international talk at this conference, together with papers from renowned scientists of the field. It is indeed because today's students are tomorrow's scientific leaders that our conference always promoted their participation and will keep on doing so thanks to the SPIE student grant policy.

If "Integrated Optics: Technology, Devices and Materials" is now one of the oldest conferences of the SPIE Optoelectronics symposium, it is, of course, because of the quality of the scientific work that has been presented through the years, but it is also because of the dedication of all the members of the program committee who accept willingly to spend a part of their summertime in building this conference and finding all the exciting invited talks that we see every year.

To them, to all the speakers and authors, to all the SPIE staff who make the logistics run so smoothly, we would like to say thank you very much and we long to see you next year.

Jean Emmanuel Broquin Gualtiero Nunzi-Conti 
Downloaded From: https://www.spiedigitallibrary.org/conference-proceedings-of-spie on 26 Apr 2023

Terms of Use: https://www.spiedigitallibrary.org/terms-of-use 